\title{
ROLE OF GOVERNMENT POLICIES IN RURAL DEVELOPMENT
}

\author{
UMESH GUPTA $^{\text {a1 }}$ AND KAMAL KISHOR AGRAWAL ${ }^{\mathrm{b}}$ \\ ab School of Business Studies, MATS University Raipur, C.G., India
}

\begin{abstract}
The central aim or focus of this paper is to highlight the role of local government (being the closest tier of government to the grassroots) in rural development. Of late, rural development has assumed global attention especially among the developing nations. It has great significance for a country like India where majority of the population, around $70 \%$ of the people, live in rural areas. The present strategy of rural development in India mainly focuses on poverty alleviation, better livelihood opportunities, provision of basic amenities and infrastructure facilities through innovative programmes of wage and self-employment. This Paper overviews the role and function of the Government and its' Policies for rural development in India. Science and technological interventions in the field of rural development have been discussed briefly and efforts being made to document some of the appropriate technologies developed by several research institutes, organizations suitable for application in rural areas are listed. The Rural Development in India is one of the most important factors for the growth of the Indian economy. India is primarily an agriculture-based country. Agriculture contributes nearly one-fifth of the gross domestic product in India. In order to increase the growth of agriculture, the Government has planned several programs pertaining to Rural Development in India. The Ministry of Rural Development in India is the apex body for formulating policies, regulations and acts pertaining to the development of the rural sector. Agriculture, handicrafts, fisheries, poultry, and diary are the primary contributors to the rural business and economy. The introduction of Bharat Nirman, a project set about by the Government of India in collaboration with the State Governments and the Panchayat Raj Institutions is a major step towards the improvement of the rural sector. The National Rural Employment Guarantee Act 2005 was introduced by the Ministry of Rural Development, for improving the living conditions and its sustenance in the rural sector of India.
\end{abstract}

KEYWORDS: Bharat Nirman, Panchayat Raj, National Rural Employment Guarantee Act

\section{PROBLEMS}

- Lack of adequate finance

- Unidentification of priority projects within the local government.

- Inability to generate internal revenue for development.

- Negative attitude of the communities

- Poor attitude of the workers it the local government.

- Rural Development In India-Schemes

- Pradhan Mantri Gram Sadak Yojana (PMGSY)

This is a scheme launched and fully sponsored by the Central Government of India. The main objective of the scheme is to connect all the habitations with more than 500 individuals residing there, in the rural areas by the means of weatherproof paved roads.

\section{Swarnjayanti Gram Swarozgar Yojana (SGSY)}

This was implemented as a total package with all the characteristics of self employment such as proper training, development of infrastructure, planning of activities, financial aid, credit from banks, organizing self help groups, and subsidies.

\section{Sampoorna Gramin Rozgar Yojana (SGRY)}

This scheme aims at increasing the food protection by the means of wage employment in the rural areas which are affected by the calamities after the appraisal of the state government and the appraisal is accepted by the Ministry of Agriculture.

\section{Indira Awaas Yojana (Rural Housing)}

This scheme puts emphasis on providing housing benefits all over the rural areas in the country.

\section{RURAL DEVELOPMENT IN INDIA- ORGANIZATIONS}

\section{Department of Rural Development in India}

This department provides services such as training and research facilities, human resource development, functional assistance to the DRDA, oversees the execution of projects and schemes.

\section{Haryana State Cooperative Apex Bank Limited}

The main purpose of the Haryana State Cooperative Apex Bank Limited is to financially assist the artisans in the rural areas, farmers and agrarian unskilled labor, small and big rural entrepreneurs of Haryana.

\section{National Bank for Agriculture and Rural Development}

The main purpose of the National Bank for Agriculture and Rural Development is to provide credit for the development of handicrafts, agriculture, small scaled industries, village industries, rural crafts, cottage industries, and other related economic operations in the rural sector. 


\section{GUPTA AND AGRAWAL: ROLE OF GOVERNMENT POLICIES IN RURAL DEVELOPMENT}

\section{Sindhanur Urban Souharda Co-operative Bank}

The main purpose of the Sindhanur Urban Souharda Co-operative Bank is to provide financial support to the rural sector.

\section{Rural Business Hubs (RBH)}

RBH was set up with the purpose of developing agriculture. The Rural Business Hubs Core Groups helps in the smooth functioning of the Rural Business Hubs.

\section{Council for Advancement of People's Action and Rural Technology (CAPART)}

The main purpose of this organization is to promote and organize the joint venture, which is emerging between the Government of India and the voluntary organizations pertaining to the development of the rural sector.

\section{POLICIES AND PLANS IN CHHATTISGARH}

- Panchayat Vibhag

- E-Panchayat

- Mahatma Gandhi National Rural Employement Guarentee Act

- National Rureal Livelihood Mission

- NREGA Call Centre Mission

- Prime Minister Road Project
- Rural Engineering Services

- Rural Development State Organization

- State Level Nodal Agency

- Rural Research Centre

- Swacchha Bharat Mission

- Hamar Chattisgarh

Five Schemes Namely

'Mukhyamantri Gram Utkarsh Yojana,' Chhattisgarh Rural Construction Scheme, Rural Development Scheme, Chhattisgarh Gaurav and Humara Chhattisgarh Schemes, have been integrated as 'Mukhyamantri Samagra Grameen Vikas Yojana' (Chief Minister's All-Round Rural Development Scheme), under which construction works related to infrastructural development in rural areas will be approved as per the local requirements.

\section{REFERENCES}

http://eprints.covenantuniversity.edu.ng

http://www.nistads.res.in/indiasnt2008/t6rural/t6rur3.htm

https://business.mapsofindia.com/rural-economy/develop ment

www.daily pioneer.com 